OPEN ACCESS

Edited by:

Michael Sauer,

University of Natural Resources and

Life Sciences, Austria

Reviewed by:

Samuel Ken-En Gan,

Bioinformatics Institute (A*STAR),

Singapore

Haidong Tan

Dalian Institute of Chemical Physics

(CAS), China

*Correspondence:

Yasir Rehman

yasir.mmg@pu.edu.pk

Specialty section:

This article was submitted to Microbial Physiology and Metabolism,

a section of the journal

Frontiers in Microbiology

Received: 18 July 2017 Accepted: 23 October 2017 Published: 07 November 2017

Citation:

Asif A, Mohsin H, Tanvir R and Rehman Y (2017) Revisiting the Mechanisms Involved in Calcium

Chloride Induced Bacterial Transformation

Front. Microbiol. 8:2169.

doi: 10.3389/fmich.2017.02169

\section{Revisiting the Mechanisms Involved in Calcium Chloride Induced Bacterial Transformation}

\author{
Azka Asif ${ }^{1}$, Hareem Mohsin ${ }^{1}$, Rabia Tanvir ${ }^{2}$ and Yasir Rehman ${ }^{1 *}$ \\ ${ }^{1}$ Department of Microbiology and Molecular Genetics, University of the Punjab, Lahore, Pakistan, ${ }^{2}$ University Diagnostic Lab, \\ Department of Microbiology, University of Veterinary and Animal Sciences, Lahore, Pakistan
}

Keywords: calcium chloride, transformation, Escherichia coli, DNA, competent cells

Bacterial transformation is a crucial part of cloning process and has been widely used in many studies (Swords, 2003; Gigova et al., 2006). The mechanism is marked by two phases, the first phase involves the uptake of the DNA across the cellular envelope and the second phase involves the setting up of the DNA in the cell as a stable genetic material (Hanahan, 1983). The procedure of transformation is of physicochemical nature rather than strictly being a chemical or a physical procedure, since the cells are manipulated with cations (or a combination of cations) and temperature imbalances to render them competent to uptake foreign DNA. It is a common understanding that the chemical manipulation is linked to the induction of competency while the physical manipulation is linked to the uptake of foreign DNA. The two methods act together to bring about the act of "artificial DNA internalization."

Over time various methods have been used to make cells competent such as by using dimethyl sulfoxide (DMSO), divalent cations, or polyehtylene glycol (PEG) (Klebe et al., 1983; Chan et al., 2013). Other than these chemical methods, electroporation has also been tested and used to induce competency (Dower et al., 1988; Yoshida and Sato, 2009; Liu et al., 2013). The use of divalent cations has been the most effective chemical treatment to bring about transformation (Day, 2004). Among various cations, divalent calcium cation $\left(\mathrm{Ca}^{2+}\right)$ has proven to be the most effective one (Weston et al., 1981) both alone (Dagert and Ehrlich, 1979) and in various combinations. A combination of divalent and monovalent ions, such as calcium and magnesium (Taketo, 1974; Wensink et al., 1974), calcium and manganese (Enea et al., 1975), calcium, rubidium, and dimethyl sulfoxide (Kushner, 1978) and other alkali metals with a prolonged incubation at $0^{\circ} \mathrm{C}$ (Taketo, 1972; Dagert and Ehrlich, 1979) has also been reported to be effective (Roychoudhury et al., 2009). Generally, all divalent cations enhance the transformation process. Hanahan (1983) found that the presence of magnesium in bacterial culture media increases the transformation efficiency by 15- to 20folds as compared to the cells grown in the absence of magnesium. He also observed that the addition of magnesium in the media $30 \mathrm{~min}$ before the time of collection of cells also enhances the transformation up to $\sim 60 \%$. However, addition of magnesium as the cells are harvested and incubated on ice enhances transformation up to $\sim 40 \%$. The addition of calcium or manganese ions has also shown almost the same stimulatory effect as that of the magnesium ions (Hanahan, 1983). However, incubation time with calcium chloride or any other divalent cation for that matter, should be optimized. It was observed that a period of $24 \mathrm{~h}$ incubation in cold calcium chloride makes the bacterial cells 20-30 times more competent and 4-6 times more efficient for transformation as compared to the cells that are obtained immediately after $\mathrm{CaCl}_{2}$ treatment (Blattner et al., 1977; Dagert and Ehrlich, 1979). Curtiss et al. (1977) experimented on E. coli strain X1776 and 
observed the effect of various set of conditions on the efficiency of transformation. He treated the bacterial culture with a combination of manganese, calcium, rubidium, and potassium ions along with DMSO and sucrose at $0^{\circ} \mathrm{C}$ followed by a heat pulse at $42^{\circ} \mathrm{C}$. However, these conditions did not give successful results when other strains of E. coli were used (Hanahan, 1983). Meselson and Yuan (1968) found these conditions promising for successful transformation in case of a strain of E. coli MM294 than the standard "calcium chloride" protocol. Bolivar et al. (1977) reported $10^{6}$ transformants when the cells were treated with calcium alone while Kushner (1978) reported to obtain $10^{7}$ transformants after treating the cells with rubidium along with calcium chloride. Norgard et al. (1978) was also able to obtain $10^{7}$ transformants with the method followed by Kushner (1978) in case of K-12 strain X1776 of E. coli. However, transformants yield varied from specie to specie and strain to strain (Mercer and Loutit, 1979). It was reported by Sjöström et al. (1972) that the optimum concentration of calcium chloride for the uptake of DNA by $S$. aureus is $0.1 \mathrm{M} \mathrm{CaCl}_{2}$. The repulsion between foreign DNA and the bacterial cell, owing to negative charges on them both, are overcome by these divalent cations. This is applicable for linear DNA fragments as well as circular DNA molecules such as plasmids (Mandel and Higa, 1970; Tsen et al., 2002). It is thought that the divalent cations bind both to the cell and the DNA, thus neutralizing the charge altogether. The calcium bound to the DNA further helps the DNA to adsorb to the competent cell (Panja et al., 2008b). Moreover, DNA binding proteins present in the cell membrane could also aid in this interaction. The anchorage of the DNA to the membrane eliminates the risk of detachment or expulsion of DNA (Clark et al., 2002). Further, the low temperatures used in transformation protocols congeals the lipid moiety and consequently restricts the fluidity of the cell membrane which strengthens calcium-cell surface interaction. In this way calcium ions, bound with cell surface as well as the foreign DNA, brings the DNA to the cell. Clark et al. (2002) showed that the relative association of divalent cations (e.g., $\mathrm{Ca}^{2+}$ ) is more with the cell membrane as compared to its association with foreign DNA, whereas certain trivalent cations (e.g., spermidine) interact more readily with the DNA ( $\mathrm{Li}$ et al., 2004). It was also reported in this study that $\mathrm{Ca}^{2+}$ has more pronounced role to play in development of competency as compared to spermidine or trivalent cations (Clark et al., 2002). Membranes absorb calcium very readily and once inside the cell the calcium ions are neutralized by membrane phosphates present on the cytosolic side (Melcrová et al., 2016). The binding of calcium ions to the membrane also cause changes in the membrane permeability $(\mathrm{Li}$ et al., 2004).

Treatment with divalents or trivalents on ice is followed by treatment with elevated temperature as a heat-shock, which produces a temperature imbalance. Molecules with increased Brownian motion outside the cell are likely to push the DNA molecule inside the cell. However, it is unclear if this kinetic force is sufficient enough to push the adsorbed DNA molecules inside. Panja et al. (2008a) studied the efficacy of cooling and heating cycles by increasing the number of cycles until maximum transformation efficiency was achieved. It was inferred that lowering of temperature actually contributes to protein loss, while heating contributes to lipid loss, and thus together these cycles increase transformation efficiency (Panja et al., 2008a) as it enlarges the pore size on the cell surface. Moreover, due to loss of lipids and proteins, the membrane is depolarized, further reducing the repulsion between the DNA molecule and the membrane. Moreover, cell density can also affect the efficiency of transformation and it has been reported that maximum competency is observed at cell density ranging from $10^{7}$ to $10^{8}$ cells $\mathrm{ml}$ in the log phase (Taketo, 1974; Norgard et al., 1978).

However, the question remains; whether the pores (through which foreign DNA enters a cell) are formed by the calcium treatment or are they naturally present. There exist natural channels, often called Bayer's bridges, in the membrane that can serve as potential pathway for DNA uptake (Dreiseikelmann, 1994; Sperandeo et al., 2007; Srivastava, 2013). Hanahan (1983) stated that the competent cells have many sites or channels and all these sites and channels have an independent chance of taking part in the uptake of DNA moving toward the process of transformation. All the cells, whether competent or not, compete for the uptake of plasmid but if only competent cells are used for the transformation, the efficiency will be increased up to 50folds as discussed by Hanahan (1983). The DNA uptake factor is the sum of all the probabilities of DNA uptake through each channel. It was reported that the chances of transformation are not increased by increasing the concentration of DNA but by the increase in the number of channels through which the uptake of DNA takes place (Hanahan, 1983; Nikaido and Vaara, 1985). Moreover, calcium has a dual role in this process; it not only neutralizes the charge but also weakens the cell membrane to produce invaginations (Stein, 1990; Thomas and Rice, 2014).

While it was known that the divalent cations help neutralize the charge, the complex ions can also serve to produce static force of attraction within the DNA molecule. This leads to the folding of DNA into a compact ball-like structure that facilitates its entry into the cell (Clark et al., 2002). A supercoiled ball like structure of the plasmid will have more chances of entering the competent cell for transformation than the extended open circular form of the plasmid. However, if the size of the DNA approaches the size of the pore, the probability of the transformation decreases sharply. When using spermidine or other trivalents, the size of the ball-like structure of DNA might exceed the size of pores in the cell membrane, which can be only solved by altering the physical parameters used in the protocol, primarily the heating and cooling cycles. Whether using divalents or trivalents, their concentrations need to be optimized such that all the phosphates of the DNA are not rendered inaccessible, because some parts of the DNA have to adsorb onto the cell surface and for that free phosphates are required, as inferred by Panja et al. (2008b).

The transformation efficiency is greatly affected by the type of the host cell, as they have different cell surface structures, especially in relation to $\mathrm{O}$-polysaccharides that protrude from the surface of the cell. These surface structures interact with the divalent cations and the DNA, thus making the cell competent 
for transformation. Different strains of E. coli, as discussed above, have been reported to show variance in transformation efficiency, owing to the differences in chemical properties of their cellular envelope (Taketo, 1972). A very dense Opolysaccharide will become a deterrent for the DNA to pass through. However, it has also been claimed that extensive removal of LPS by excessive ethanol-pretreatment reduces transformation efficiency (Roychoudhury et al., 2009). This can be explained by the aforementioned hypothesis that the DNA first attaches to some external component of the cell membrane, which then assists its movement inside the cell.
Along with the density, the composition of the O-polysaccahride also plays a role in the reception of the incoming DNA molecule (Lacks, 1977). Moreover, calcium ions also interacts with the membrane and at $100 \mathrm{mM} \mathrm{CaCl} 2$ concentration, almost all calcium is absorbed by the cell membrane's phosphatidylcholine and phosphatidylserine (Melcrová et al., 2016). Therefore, the membrane properties play a major role in DNA adsorption.

The evidences clearly indicate that the physical and chemical treatments used during transformation, i.e., the temperature imbalances and $\mathrm{CaCl}_{2}$ treatment, help deal with the barriers

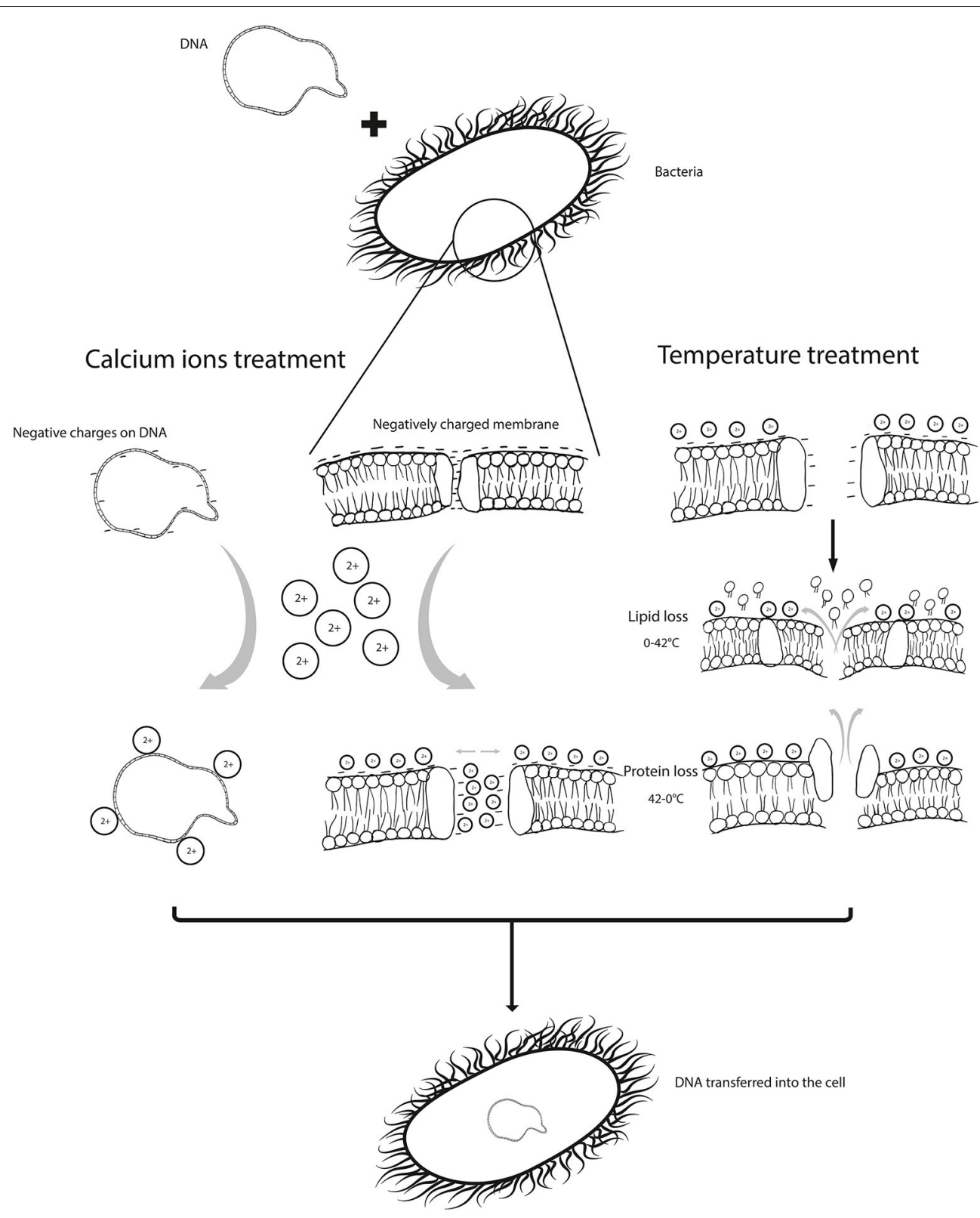

FIGURE 1 | shows the barriers /limitations in uptake of DNA by a bacterial cell, which are; the repulsion caused by negative charges on the cell membrane and DNA and the porosity of the membrane. These are manipulated by chemical treatment, such as calcium ions which neutralize negative charges. Physical parameters can be applied to improve porosity and permeability. 
to DNA uptake, such as charge repulsions and pore sizes (Figure 1). Magnesium and calcium combinations are seldom used in transformation protocols, the importance of which should be considered. A combination of divalent and trivalent cations with prolonged incubation times can be suggested to improve the transformation efficiency; as in addition to the charge stabilization, trivalent cations can compact DNA, further aiding its internalization. Bacterial cells could also be grown in presence of $\mathrm{CaCl}_{2}$ and $\mathrm{MgCl}_{2}$ before inducing competency. Heating and cooling cycles used just once in transformation protocols could also be increased to three times for higher

\section{REFERENCES}

Blattner, F. R., Williams, B. G., Blechl, A. E., Denniston-Thompson, K., Faber, H. E., Furlong, L., et al. (1977). Charon phages: safer derivatives of bacteriophage lambda for DNA cloning. Science 196, 161-169. doi: 10.1126/science. 847462

Bolivar, F., Rodriguez, R. L., Greene, P. J., Betlach, M. C., Heyneker, H. L., Boyer, H. W., et al. (1977). Construction and characterization of new cloning vehicle. II. A multipurpose cloning system. Gene 2, 95-113.

Chan, W.-T., Verma, C. S., Lane, D. P., and Gan, S. K. (2013). A comparison and optimization of methods and factors affecting the transformation of Escherichia coli. Biosci. Rep. 33:e00086. doi: 10.1042/BSR20 130098

Clark, J., Hudson, J., Mak, R., McPherson, C., and Tsin, C. (2002). A look at transformation efficiencies in E. coli: An investigation into the relative efficiency of $E$. coli to take up plasmid DNA treated with the complex molecular trivalent cations spermine or spermidine within the context of the Hanahan protocol for transformation. J. Exp. Microbiol. Immunol. 2, 68-80.

Curtiss, R., III, Inoue, M., Pereira, D., Hsu, J. C., Alexander, L., and Rock, L. (1977). "Construction and use of safer bacterial host strains for recombinant DNA research," in Molecular Cloning of Recombinant DNA, eds W. A. Scott and R. Werner (New York, NY: Academic Press), 99-114.

Dagert, M., and Ehrlich, S. (1979). Prolonged incubation in calcium chloride improves the competence of Escherichia coli cells. Gene 6, 23-28. doi: 10.1016/0378-1119(79)90082-9

Day, M. J. (2004). “Transformation," in Microbial Evolution, eds R. V. Miller and M. J. Day (Washington, DC: American Society of Microbiology Press), 158-172.

Dower, W. J., Miller, J. F., and Ragsdale, C. W. (1988). High efficiency transformation of E. coli by high voltage electroporation. Nucleic Acids Res. 16, 6127-6145. doi: 10.1093/nar/16.13.6127

Dreiseikelmann, B. (1994). Translocation of DNA across bacterial membranes. Microbiol. Rev. 58, 293-316.

Enea, V., Vovis, G. P., and Zinder, N. D. (1975). Genetic studies with heteroduplex DNA of bacteriophage fl. Asymmetric segregation, base correction and implications for the mechanism of genetic recombination. J. Mol. Biol. 96, 495-509. doi: 10.1016/0022-2836(75)90175-8

Gigova, L., Petrova, N., Dimova, S., and Staneva, D. (2006). Cloning of nifM-like gene from Sinorhizobium meliloti. Comptes rendus de l'Acad'emie bulgare des Sci. 59, 865-868.

Hanahan, D. (1983). Studies on transformation of Escherichia coli with plasmids. J. Mol. Biol. 166, 557-580. doi: 10.1016/S0022-2836(83)80284-8

Klebe, R. J., Harriss, J. V., Sharp, Z. D., and Douglas, M. G. (1983). A general method for polyethylene-glycol-induced genetic transformation of bacteria and yeast. Gene 25, 333-341. doi: 10.1016/0378-1119(83)90238-X

Kushner, S. R. (1978). An Improved Method for Transformation of Escherichia coli with ColEl Derived Plasmids. Amsterdam: Elsevier.

Lacks, S. A. (1977). Binding and Entry of DNA in Bacterial Transformation Microbial Interactions (Receptors and Recognition, Series, B., Vol. 3). London: Chapman and Hall.

Li, W., Xie, H., Xie, Z., Lu, Z., Ou, J., Chen, X., et al. (2004). Exploring the mechanism of competence development in Escherichia coli using transformation efficiencies. These conditions need to be adjusted and optimized for different bacterial species and strains, owing to the differences in their surface properties. However, there is a need for concrete evidences based on experiments designed exclusively to elaborate this phenomenon.

\section{AUTHOR CONTRIBUTIONS}

AA and HM drafted the manuscript. YR put forward the idea of the manuscript and edited the manuscript to the final form. RT helped in the write up of the manuscript.

quantum dots as fluorescent probes. J. Biochem. Biophys. Methods 58, 59-66. doi: 10.1016/S0165-022X(03)00154-4

Liu, C., Xie, X., Zhao, W., Liu, N., Maraccini, P. A., Sassoubre, L. M., et al. (2013). Conducting nanosponge electroporation for affordable and high-efficiency disinfection of bacteria and viruses in water. Nano Lett. 13, 4288-4293. doi: 10.1021/nl402053z

Mandel, M., and Higa, A. (1970). Calcium-dependent bacteriophage DNA infection. J. Mol. Biol. 53, 159-162. doi: 10.1016/0022-2836(70)90051-3

Melcrová, A., Pokorna, S., Pullanchery, S., Kohagen, M., Jurkiewicz, P., Hof, M., et al. (2016). The complex nature of calcium cation interactions with phospholipid bilayers. Sci. Rep. 6:38035. doi: 10.1038/srep 38035

Mercer, A. A., and Loutit, J. S. (1979). Transformation and transfection of Pseudomonas aeruginosa: effects of metal ions. J. Bacteriol. 140, 37-42.

Meselson, M., and Yuan, R. (1968). DNA restriction enzyme from E. coli. Nature 217, 1110-1114. doi: 10.1038/2171110a0

Nikaido, H., and Vaara, M. (1985). Molecular basis of bacterial outer membrane permeability. Microbiol. Rev. 49, 1.

Norgard, M. V., Keem, K., and Monahan, J. J. (1978). Factors affecting the transformation of Escherichia coli strain $\chi 1776$ by pBR322 plasmid DNA. Gene 3, 279-292. doi: 10.1016/0378-1119(78)90038-0

Panja, S., Aich, P., Jana, B., and Basu, T. (2008a). How does plasmid DNA penetrate cell membranes in artificial transformation process of Escherichia coli? Mol. Membr. Biol. 25, 411-422. doi: 10.1080/09687680802187765

Panja, S., Aich, P., Jana, B., and Basu, T. (2008b). Plasmid DNA binds to the core oligosaccharide domain of LPS molecules of E. coli cell surface in the $\mathrm{CaCl} 2$-mediated transformation process. Biomacromolecules 9, 2501-2509. doi: 10.1021/bm8005215

Roychoudhury, A., Basu, S., and Sengupta, D. N. (2009). Analysis of comparative efficiencies of different transformation methods of $E$. coli using two common plasmid vectors. Indian J. Biochem. Biophys. 46, 395-400.

Sjöström, J.-E., Lindberg, M., and Philipson, L. (1972). Transfection of Staphylococcus aureus with bacteriophage deoxyribonucleic acid. J. Bacteriol. 109, 285-291.

Sperandeo, P., Cescutti, R., Villa, R., Di Benedetto, C., Candia, D., Dehò, G., et al. (2007). Characterization of lptA and lptB, two essential genes implicated in lipopolysaccharide transport to the outer membrane of Escherichia coli. J. Bacteriol. 189, 244-253. doi: 10.1128/JB.01126-06

Srivastava, S. (2013). Transformation. Genetics of Bacteria. New Delhi: Springer India.

Stein, S. (1990). "Production and analysis of proteins by recombinant DNA technology," in Fundamentals of Protein Biotechnology (CRC Press).

Swords, W. E. (2003). "Chemical Transformation of E. coli", in E. coli Plasmid Vectors: Methods and Applications, eds N. Casali and A. Preston (Totowa, NJ; Oxford: Humana; Blackwell), 49-53.

Taketo, A. (1972). Sensitivity of Escherichia coli to viral nucleic acid: v. competence of calcium-treated cells. J. Biochem. 72, 973-979. doi: 10.1093/oxfordjournals.jbchem. a129988

Taketo, A. (1974). Sensitivity of Escherichia coli to viral nucleic acid. J. Biochem. 75, 895-904. doi: 10.1093/oxfordjournals.jbchem.a130463 
Thomas, K. J., and Rice, C. V. (2014). Revised model of calcium and magnesium binding to the bacterial cell wall. Biometals 27, 1361-1370. doi: 10.1007/s10534-014-9797-5

Tsen, S.-D., Fang, S.-S., Chen, M.-J., Chien, J.-Y., Lee, C.-C., and Tsen, D. H. (2002). Natural plasmid transformation in Escherichia coli. J. Biomed. Sci. 9, 246-252. doi: 10.1159/000059425

Wensink, P. C., Finnegan, D. J., Donelson, J. E., and Hogness, D. S. (1974). A system for mapping DNA sequences in the chromosomes of Drosophila melanogaster. Cell 3, 315-325. doi: 10.1016/0092-8674(74) 90045-2

Weston, A., Brown, M. G., Perkins, H. R., Saunders, J. R., and Humphreys, G. O. (1981). Transformation of Escherichia coli with plasmid deoxyribonucleic acid: calcium-induced binding of deoxyribonucleic acid to whole cells and to isolated membrane fractions. J. Bacteriol. 145, 780-787.
Yoshida, N., and Sato, M. (2009). Plasmid uptake by bacteria: a comparison of methods and efficiencies. Appl. Microbiol. Biotechnol. 83, 791. doi: 10.1007/s00253-009-2042-4

Conflict of Interest Statement: The authors declare that the research was conducted in the absence of any commercial or financial relationships that could be construed as a potential conflict of interest.

Copyright (C) 2017 Asif, Mohsin, Tanvir and Rehman. This is an open-access article distributed under the terms of the Creative Commons Attribution License (CC BY). The use, distribution or reproduction in other forums is permitted, provided the original author(s) or licensor are credited and that the original publication in this journal is cited, in accordance with accepted academic practice. No use, distribution or reproduction is permitted which does not comply with these terms. 